\section{Devil's Day}

Andrew Michael Hurley

John Murray, 2017, HB, 340pp, E12.99, 9781473619869

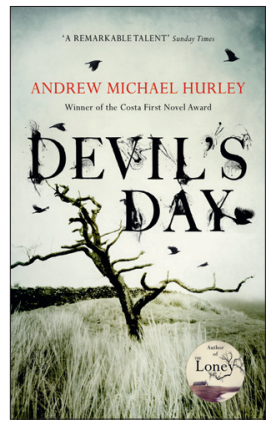

\section{EVIL BOTH MUNDANE AND SUPERNATURAL}

Andrew Michael Hurley's first novel The Loney was released in a limited print run by genre publisher Tartarus Press. Given a wider release by publisher John Murray, it went on to win the 2015 Costa First Novel Award. With Devil's Day, Hurley's second novel, it's interesting to see the author's literary preoccupations emerge: childhood, children with learning difficulties, religious belief, evil both mundane and supernatural, and the countryside. In Hurley's books, the countryside can be a place of harshness and danger.

Devil's Day concerns the return home of John Pentecost to the Lancashire farm of his childhood. Pentecost works as a teacher in Suffolk and is returning to the Briardale Valley and the oddly named Endlands to assist with the traditional redrawing of the farm boundaries. The Gaffer, the family patriarch and Pentecost's grandfather, has died, and Pentecost finds himself in an environment of feuds, disappearances, secrets, and menace. As with The Loney, Hurley excels at creating threatening and cruel antagonists.

The people of the Endlands have a traditional celebration (the Devil's Day of the title) that originates in the deaths of 13 local people in a blizzard a century past. In a folkloric twist, the deaths are reputedly caused by the Devil, who wrapped himself in the fleece of a slaughtered ewe and, flitting from house to house, brought disaster on the Endlands. As the novel unfolds, the folklore Devil jumping into people's bodies is contrasted with more everyday (but equally dangerous) impulses towards doing evil.

The author depicts the continuity of generations working on the farm via flashbacks and a framing device. However, it's an unsentimental milieu that Hurley creates - one of hard lives, abattoirs, and gruesome accidents. Although I don't think the novel develops Pentecost's decision (and his wife Kat's decision) regarding life in the Endlands sufficiently, there are enough glimpses of the grotesque and the strange for Devil's Day to be enjoyable.

\section{Tony Nixon,}

Assistant Editor, BJGP.

Tony.Nixonঝrcgp.org.uk

DOI: https://doi.org/10.3399/bjgp18X698765

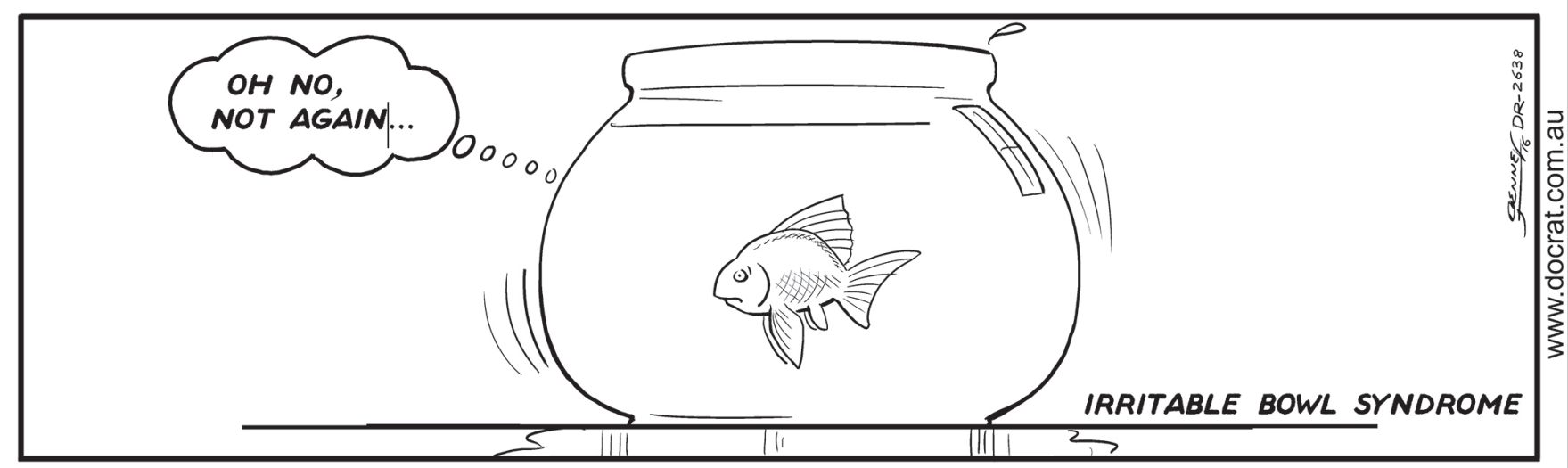

